\title{
Research on Practice Base Construction for Professional Degree Graduate Majoring Mechanical Engineering
}

\author{
Zhenhui Luan ${ }^{a^{*}}$, Xuebin Lib, Yijun Zhou ${ }^{\mathrm{c}}$ \\ College of Mechanical Engineering, Anhui University of Science and Technology, \\ Huainan 232001, China \\ *Corresponding author
}

\begin{abstract}
The construction of practice base is an important guarantee of education quality of professional degree graduate. In order to improve education quality of professional degree student, the authors analyzed existing problems and the causes of present construction of practice base, proposed the specific reform measures for practice base construction, put forward the concrete measures and suggestions to strengthen practice base construction, provided some conditions for enterprise to participate practice base construction, determined some appropriate enterprises as practice bases for professional degree graduate. After practice, it has achieved good results.
\end{abstract}

Keywords-Practice base; Construction; Professional degree graduate; Mechanical engineering field; Enterprise

\section{INTRODUCTION}

The training target for professional degree graduate confirmed by the National Engineering Master Major Degree Education Steering Committee is to master a solid foundation in the professional field theory and broad professional knowledge, to have strong ability to solve practical problems, to undertake professional technical or management work [1]. The training goal determines that the professional degree students must have a strong practical ability. The construction of practice base is an important guarantee for the quality of education professional degree students.

\section{EXISTING PROBLEMS}

Practice base is a comprehensive functions body which is built by the schools and the practice units based on the contract agreement for promoting common development of colleges, students and practice units, integrating teaching, scientific research, production and education [2]. Practice base should enable the students to have a purposed, planned and organized to participate in professional practice, so as to improve the students' professional ability [3], but the situation of the practice base is unsatisfactory.

Literature [4] had finished an investigation on the situation of practice base construction for full-time master degree student. The results of the investigation were shown in table 1. In table 1, from No.1 to No.4 were about the basic training conditions of the practice base, and the students' satisfaction with this section was below $70 \%$, and it showed that the conditions of the practice base could not satisfy students' practical skills. There is still much work to be done in practice base construction.

From No.5 to No.9 were about training ability for students of the practice base, and the students' satisfaction with this section was $64.6 \%--72.1 \%$. That is to say, most students thought that the practice base could improve their practical ability, but many students were still dissatisfied with their technological innovation ability, theoretical level and the ability to solve engineering problems.

From No.10 to No.12 were about mentor's professional quality and responsibility for practical teaching, and the students' satisfaction with this section was $63.9 \%--77.0 \%$. Many students were satisfied with their mentor's professional quality, but dissatisfied with their responsibility. 
TABLE I.

THE RESULTS OF INVESTIGATION

\begin{tabular}{|c|c|c|c|c|}
\hline \multirow{2}{*}{$\begin{array}{c}\text { Serial } \\
\text { number }\end{array}$} & \multirow{2}{*}{ Items } & \multicolumn{3}{|c|}{ Degree of satisfaction [\%] } \\
\cline { 3 - 5 } & Satisfactory & General & Unsatisfactory \\
\hline 1 & Hardware facilities of practice base & 68.1 & 27.2 & 4.7 \\
\hline 2 & Software facilities of practice base & 69.3 & 23.1 & 7.6 \\
\hline 3 & Curriculum of practice base & 65.3 & 26.5 & 8.2 \\
\hline 4 & Management system of practice base & 68.1 & 25.2 & 6.7 \\
\hline 5 & Improve theoretical level & 66.7 & 25.9 & 7.4 \\
\hline 6 & Improve practical operation ability & 72.1 & 20.4 & 7.5 \\
\hline 7 & Improve computer application ability & 66.6 & 25.9 & 7.5 \\
\hline 8 & Improve innovation ability & 64.6 & 23.1 & 12.3 \\
\hline 9 & Improve ability to solve engineering problems & 68.0 & 20.4 & 11.6 \\
\hline 10 & Mentor's responsibility for practical teaching & 63.9 & 22.9 & 13.2 \\
\hline 11 & Mentor's ability to practice teaching & 76.4 & 15.0 & 8.6 \\
\hline 12 & Mentor's professional quality & 77.0 & 18.5 & 4.5 \\
\hline
\end{tabular}

\section{CAUSE ANALYSIS}

\section{A. Participation enthusiasm of enterprise is not high.}

Economic benefit is the eternal theme of enterprise. Economic interest is the most fundamental driving force of cooperation between schools and enterprises. Some companies think that the practice base will not bring economic benefit to the enterprise, and see the practice base as an additional burden. Others think that the students will affect the normal production of the enterprise, and there are safety concerns. So their participation enthusiasm is not high.

\section{B. Responsibility and strength are not clear.}

During the construction of the practice base, many problems between the cooperation of enterprise and school have not been solved well. For example, how to invest to the practice base, how to arrange teaching content for the graduate students, how to prevent students accident, how to share the value created by students, and so forth? These problems result in a lack of initiative in both school and enterprise.
C. The relevant laws and regulations are not sound.

School and company belong to different government departments. The cooperation between school and enterprise needs to be coordinated by the competent authorities, and many aspects need to be normalized by laws or regulations, such as security responsibility, profit distribution, technology transfer, risk prevention and so on.

\section{COUNTERMEASURES AND SUGGESTIONS}

Practice base is the long-term stability of the place. The construction of the base is very important to improve the quality of the graduate students [5]. So we should further improve the understanding of the importance of the practice base, and can do something from three aspects below.

\section{A. Schools}

- The school should actively enhance the cooperation of school and enterprises, develop a long-term, scientific practice base construction.

- The school should introduce advanced technology and scientific and technological achievements into the practice base, provide training opportunities for employees of the enterprises, build an industryuniversity-research cooperation mechanism with winwin cooperation with the enterprise [6]. 
- The school should choose the enterprise as the practice base whose major and specifics are relatively in line with yourself.

\section{B. Enterprises}

- Enterprise should have cooperation motivation to participate in university-enterprise cooperation of cultivating the graduate students.

- Enterprise should have good social responsibility, and understand the training requirements of the professional degree graduate students.

- Enterprise should have some advanced and representative in the field of industry, its management operation mechanism is relatively smooth [7].

- Enterprise should have a good base for hardware facilities.

- Enterprise should have a strong research and development group.

\section{Government}

- The state should make laws to regulate the behavior of schools and enterprises for the construction of the practice base, and set implementation principles and standard of execution.

\section{IMPLEMENTATION OF PRACTICE BASE}

In order to improve the practice quality of the graduate students, through my classmates, we determined China Coal Construction Group as the practice base. The group is the only high-tech construction enterprise in Anhui province. It has the special grade qualification of mine engineering construction, housing construction, municipal public utilities construction, mechanical and electrical installation, highway engineering construction. And it has the qualifications (level 1) of tunnel, railway, garden, decoration, steel structure, road maintenance and other professional contracting qualifications. Its main business includes total contract of mine engineering construction, mine freezing construction, mine drilling construction, shield construction, real estate development, and so on. It has passed "three standards body" authentication of quality, environment, occupational health and safety [8].

According to the students' interest, we chose mine drilling construction as the internship contents. Drilling construction includes drilling machinery, drilling technology, organization and management, and so on. Drilling machinery is a complex system. It includes power system, lifting system, transmission system, rotating system, circulatory system, control system, base system and auxiliary equipment system [9].

The rotating system includes rotary table, drill bit, drill stem, bit guide and so on. The bit guide is the key to ensure the well quality. One graduate student chose the guide as his research topic. He analyzed comprehensively the forces of the drill bit and the stem, analyzed the impact of the cone of the bit, designed the guide structure and the hydraulic control system of the guide, wrote a dissertation, and the guide has been granted a patent for invention.

\section{SUMMARY}

In view of the present situation of the practice base construction, the paper analyzed the causes from three aspects, gave some suggestions and some conditions for the enterprise to participate the construction of the practice base. We chose China Coal Construction Group as the practice base for professional degree graduate student. We work with the group to develop training program, to guide student practice, to negotiate students' issues, to guide student dissertation, to share students' innovations. We have a good time cooperating with the enterprise. In the future, we will strengthen the construction of practice base, and try our best to improve our professional degree graduate practice quality.

\section{ACKNOWLEDGMENT}

The research work was supported by Anhui University of Science and Technology Major Teaching Reform Project (2013-30).

\section{REFERENCES}

[1] G. Eason, B. Noble, and I.N. Sneddon, "On certain integrals of Lipschitz-Hankel type involving products of Bessel functions," Phil. Trans. Roy. Soc. London, vol. A247, pp. 529-551, April 1955.

[2] J. Clerk Maxwell, A Treatise on Electricity and Magnetism, 3rd ed., vol. 2. Oxford: Clarendon, 1892, pp.68-73.

[3] I.S. Jacobs and C.P. Bean, "Fine particles, thin films and exchange anisotropy," in Magnetism, vol. III, G.T. Rado and H. Suhl, Eds. New York: Academic, 1963, pp. 271-350.

[4] K. Elissa, "Title of paper if known," unpublished.

[5] R. Nicole, "Title of paper with only first word capitalized," J. Name Stand. Abbrev., in press.

[6] Y. Yorozu, M. Hirano, K. Oka, and Y. Tagawa, "Electron spectroscopy studies on magneto-optical media and plastic substrate interface," IEEE Transl. J. Magn. Japan, vol. 2, pp. 740-741, August 1987 [Digests 9th Annual Conf. Magnetics Japan, p. 301, 1982].

[7] M. Young, The Technical Writer's Handbook. Mill Valley, CA: University Science, 1989. 